OPEN ACCESS

Edited by:

Zhenjun Yang,

Peking University, China

Reviewed by: Ahmed Elkamhawy,

Mansoura University, Egyp

Rupesh V. Chikhale,

University of Cambridge,

United Kingdom

*Correspondence:

Lars M. Ittner

lars.ittner@mq.edu.au

Specialty section: This article was submitted to Medicinal and Pharmaceutical

Chemistry,

a section of the journa

Frontiers in Chemistry

Received: 22 September 2021 Accepted: 16 November 2021

Published: 13 December 2021

Citation:

Ariawan D, Au C, Paric E, Fath T, Ke YD, Kassiou M, van Eersel J and Ittner LM (2021) The Nature of Diamino

Linker and Halogen Bonding Define

Selectivity of Pyrrolopyrimidine-Based

LIMK1 Inhibitors.

Front. Chem. 9:781213.

doi: 10.3389/fchem.2021.781213

\section{The Nature of Diamino Linker and} Halogen Bonding Define Selectivity of Pyrrolopyrimidine-Based LIMK1 Inhibitors

\author{
Daryl Ariawan ${ }^{1}$, Carol Au ${ }^{1}$, Esmeralda Paric ${ }^{1}$, Thomas Fath ${ }^{1}$, Yazi D. Ke ${ }^{1}$, Michael Kassiou ${ }^{2}$, \\ Janet van Eersel ${ }^{1}$ and Lars M. Ittner ${ }^{1 *}$
}

${ }^{1}$ Dementia Research Centre, Department of Biomedical Science, Faculty of Medicine and Health Sciences, Macquarie University, Sydney, NSW, Australia, ${ }^{2}$ School of Chemistry, The University of Sydney, Darlington, NSW, Australia

The LIM-domain kinase (LIMK) family consists of two isoforms, LIMK1 and LIMK2, which are highly homologous, making selective inhibitor development challenging. LIMK regulates dynamics of the actin cytoskeleton, thereby impacting many cellular functions including cell morphology and motility. Here, we designed and synthesised analogues of a known pyrrolopyrimidine LIMK inhibitor with moderate selectivity for LIMK1 over LIMK2 to gain insights into which features contribute to both activity and selectivity. We incorporated a different stereochemistry around a cyclohexyl central moiety to achieve better selectivity for different LIMK isoforms. Inhibitory activity was assessed by kinase assays, and biological effects in cells were determined using an in vitro wound closure assay. Interestingly, a slight change in stereochemistry alters LIMK isoform selectivity. Finally, a docking study was performed to predict how the new compounds interact with the target.

Keywords: LIMK, kinase inhibitor, SAR, cofilin phosphorylation, actin cytoskeleton

\section{INTRODUCTION}

The LIM-domain kinase (LIMK) are a family of serine/threonine protein kinases that act downstream of Rho GTPases. Cofilin, the known LIMK substrate, is a key regulator on actin skeleton dynamics (Bernard 2007; Scott and Olson 2007). LIMKs phosphorylate cofilin at the Ser3 position. Once phosphorylated, cofilin can no longer bind to actin, leading to the accumulation of actin polymers (Tanaka et al., 2018; Ben Zablah et al., 2020). Aside from actin cytoskeletal regulation, LIMKs also play an important role in microtubule organisation (Bernard 2007; Scott and Olson 2007; Prunier et al., 2017).

The increased activity of the LIMK1 isoform has been associated with several diseases including Alzheimer's diseases (AD) (Heredia et al., 2006; Piccioli and Littleton 2014), cancer (Davila et al., 2007; Kang et al., 2021; Shi et al., 2021), and HIV (Vorster et al., 2011; Wen et al., 2014). One of the hallmarks of $\mathrm{AD}$ is characterised by deposition of the $\beta$-amyloid peptide (A $\beta$ ) (Murphy and Levine 2010). A $\beta$ deposition has a detrimental effect on actin cytoskeleton, and recent studies indicated involvement of the Rho-GTPase pathway (Rush et al., 2018). LIMK1 inhibition has shown protection against $\mathrm{A} \beta$ toxicity in primary neurons and mice (Heredia et al., 2006; Henderson et al., 2019).

Inhibition of LIMK1 also shows beneficial effects in cancer. Accordingly, overexpression of LIMK1 in breast cancer cell lines MCF-7 and MDA-MB-231 increased their motility, while 
A<smiles>C=N/N=C(/Nc1cccc(Br)c1)N1CCN(c2ncnc3[nH]cc(C)c23)C[C@H]1C</smiles>

1: Lead compound LIMK1 IC $\mathrm{C}_{50}=0.5 \mathrm{nM}$ LIMK2 IC ${ }_{50}=0.9 \mathrm{nM}$<smiles>COc1ccc(NC(=O)Nc2ccc(-c3ncnc4[nH]cc(C)c34)cc2)cc1</smiles>

2

LIMK1 IC $\mathrm{IO}_{50}=35 \mathrm{nM}$ LIMK2 $\mathrm{IC}_{50}=$ not determined<smiles>COC(=O)c1ccc2[nH]c(C3CCN(c4ncnc5[nH]cc(Cl)c45)CC3)nc2c1</smiles>

3

LIMK1 IC ${ }_{50}=38 \mathrm{nM}$ LIMK2 IC ${ }_{50}=$ not determined<smiles>CN(C)C(=O)Oc1cccc(NC(=O)C2(CN)CCN(c3ncnc4[nH]cc(Cl)c34)CC2)c1</smiles>

4

LIMK1 $\mathrm{IC}_{50}=24 \mathrm{nM}$

LIMK2 IC ${ }_{50}=1.6 \mathrm{nM}$

B

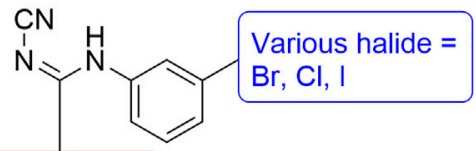

This work:<smiles>Cc1c[nH]c2ncnc(N)c12</smiles>

FIGURE 1 | (A) Structure of known pyrrolopyrimidine LIMK inhibitor and their inhibitor profile. (B) Scaffold modification in this work.

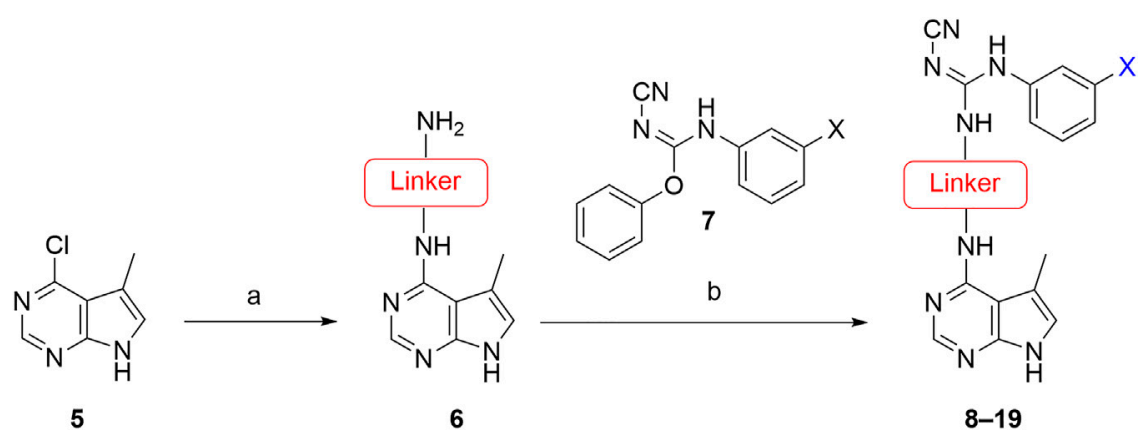

SCHEME 1 | General synthetic procedure. Reagents and condition: (A) diaminoalkane linker, diisopropylethylamine, isopropanol, reflux, 16 h, 50-97\%; (B) cyanoguanidine $\mathbf{7}$, triethylamine, MeCN, reflux, 16 h, 16\%-39\%.

inhibition of LIMK1 attenuated this effect (Yoshioka et al., 2003). Targeting LIMK1 in lung cancer cells inhibits cell proliferation and induces apoptosis (Zhang et al., 2021). Thus, LIMK1 is a promising drug target, potentially for a range of diseases.

Several LIMK1 inhibitors based on the pyrrolopyrimidine scaffold have been reported (Figure 1) (Harrison et al., 2009; Boland et al., 2015; Yin et al., 2015; Yi et al., 2017). Compound 1 was reported as part of the development of potent LIMK2 inhibitors (Harrison et al., 2009) but has a slightly higher activity against LIMK1. Accordingly, compound $\mathbf{1}$ was reported to have an $\mathrm{IC}_{50}$ of 0.5 and $0.9 \mathrm{nM}$ for inhibiting LIMK1 and LIMK2, respectively (Harrison et al., 2009). In this work, we report modifications of the central piperidine linker motif to explore the effects of conformational flexibility and halogen exchange of the phenyl cyanoguanidine motif to probe LIMK activity and selectivity (Figure 1B). We tested the 


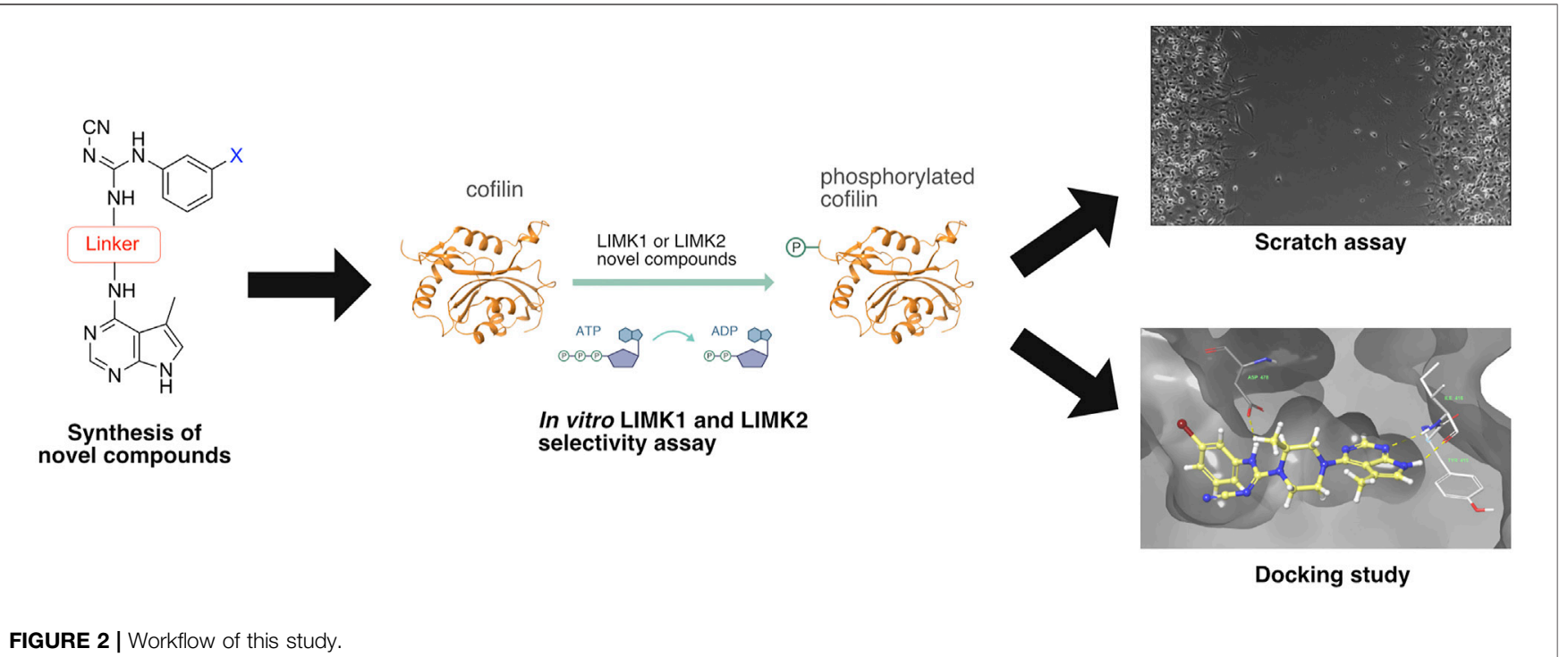

FIGURE 2 | Workflow of this study.
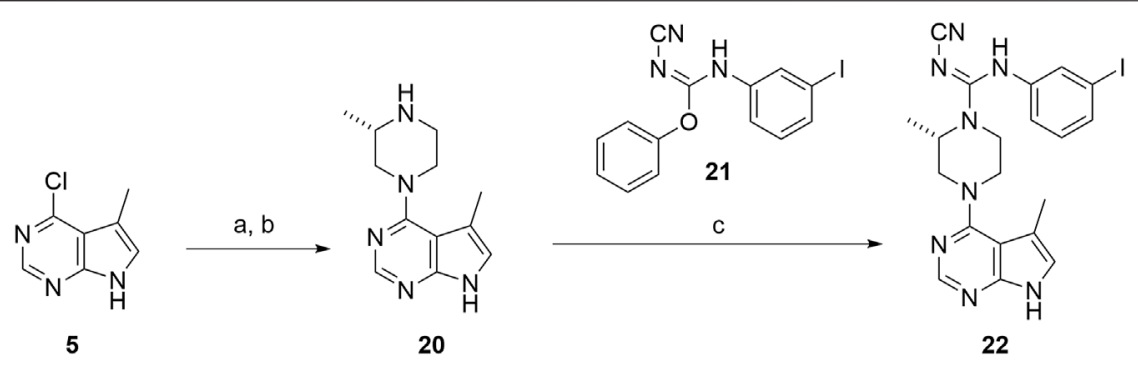

SCHEME 2 | Synthesis of iodide analogues of compound 1. Reagents and condition: (A) (S)-tert-butyl 2-methylpiperazine-1-carboxylate, diisopropylethylamine, isopropanol, reflux, 16 h; (B) 50\% TFA in DCM, rt, 3 h, 90\% over two steps; (C) cyanoguanidine 21, triethylamine, MeCN, reflux, 16 h, $8 \%$.

compounds against LIMK1 and LIMK2 to explore the selectivity and their effect on cellular based assay (Figure 2).

\section{RESULTS AND DISCUSSION}

The approach for investigating different amine linkers is described in Scheme 1. Briefly, the nucleophilic substitution of chloropyrrolopyrimidine (5) with various diamino alkane linkers afforded the desired amine derivatives (6) (Scheme 1). These amines were then converted to target compounds 8-19 by reaction with a range of halogen-substituted phenyl cyanocarbamamimidates (7), (Scheme 1) (Harrison et al., 2009). A structure-activity relationship for compounds 8-19 was initially established by measuring inhibition against LIMK1 at a concentration of $0.1 \mu \mathrm{M}$ for each compound (Table 1).

Substituting the piperidine linker motif in $\mathbf{1}$ with an ethyl linker (9) decreased inhibitory activity at LIMK1 by threefold when assayed at $0.1 \mu \mathrm{M}$ despite the similar distance between the two nitrogens in the linker (Table 1). Increasing the linker chain to a propyl motif (12) abolished the inhibitory activity while the longer butyl linker (15) restored the inhibitory activity to $47 \%$.
Incorporating the conformationally restricted 1,4diaminocyclohexane linker (18) increased the inhibitory activity to $69 \%$. Thus, it can be implied that the ring linker is needed for hydrophobic interaction within the binding pocket.

We next turned our attention to the halogen at the phenyl cyanoguanidine motif. Chloride analogues with ethyl and butyl linkers (8 and 14, respectively) completely abolished inhibitory activity. The propyl linker, chloride analogue 11, displayed a minimal inhibitory effect of $15 \%$, while with the 1,4-cyclohexyl linker, the chloride analogue $\mathbf{1 7}$ decreased the inhibitory activity compared to the bromide analogue 18 from $69 \%$ to $42 \%$, respectively. Iodide substitution with the ethyl linker (7) showed a twofold decrease in inhibitory activity compared to 9. Using the propyl linker motif, iodide analogue $\mathbf{1 3}$ gave a similar inhibitory profile to chloride analogue 11. For the butyl and cyclohexyl linkers, iodide substitution (16 and 19, respectively) gave similar potencies to bromide analogues (15 and 18).

Given the LIMK1 inhibition of the cyclohexyl analogues 17-19, we next investigated the amino 1,2-diaminocyclohexyl analogues 23-26 (Table 2). We were furthermore interested to see the effects of changing bromide to iodide in the lead compound 1. Compound 22, the iodide analogue of $\mathbf{1}$, was synthesised in a similar fashion (Scheme 2). 


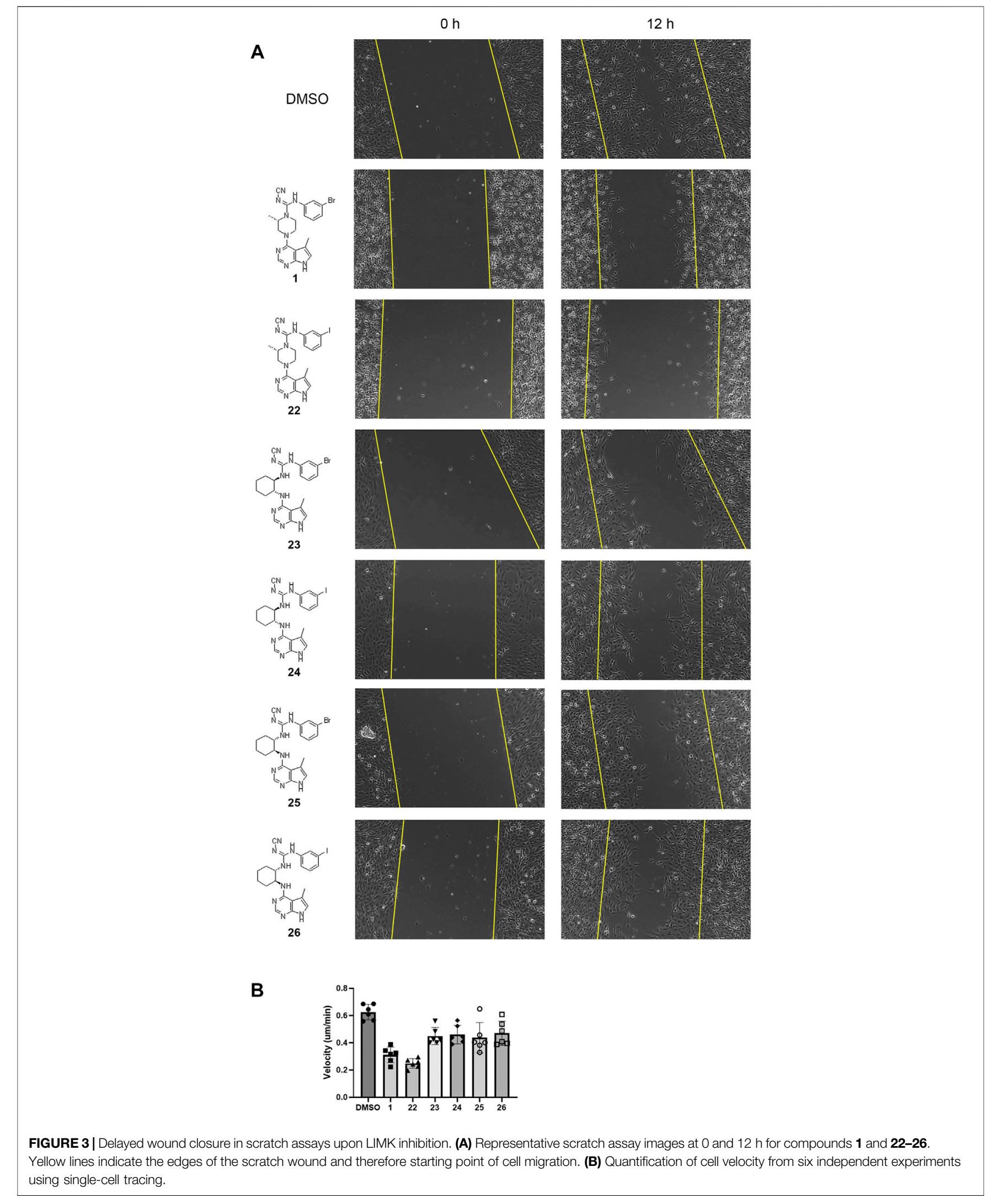



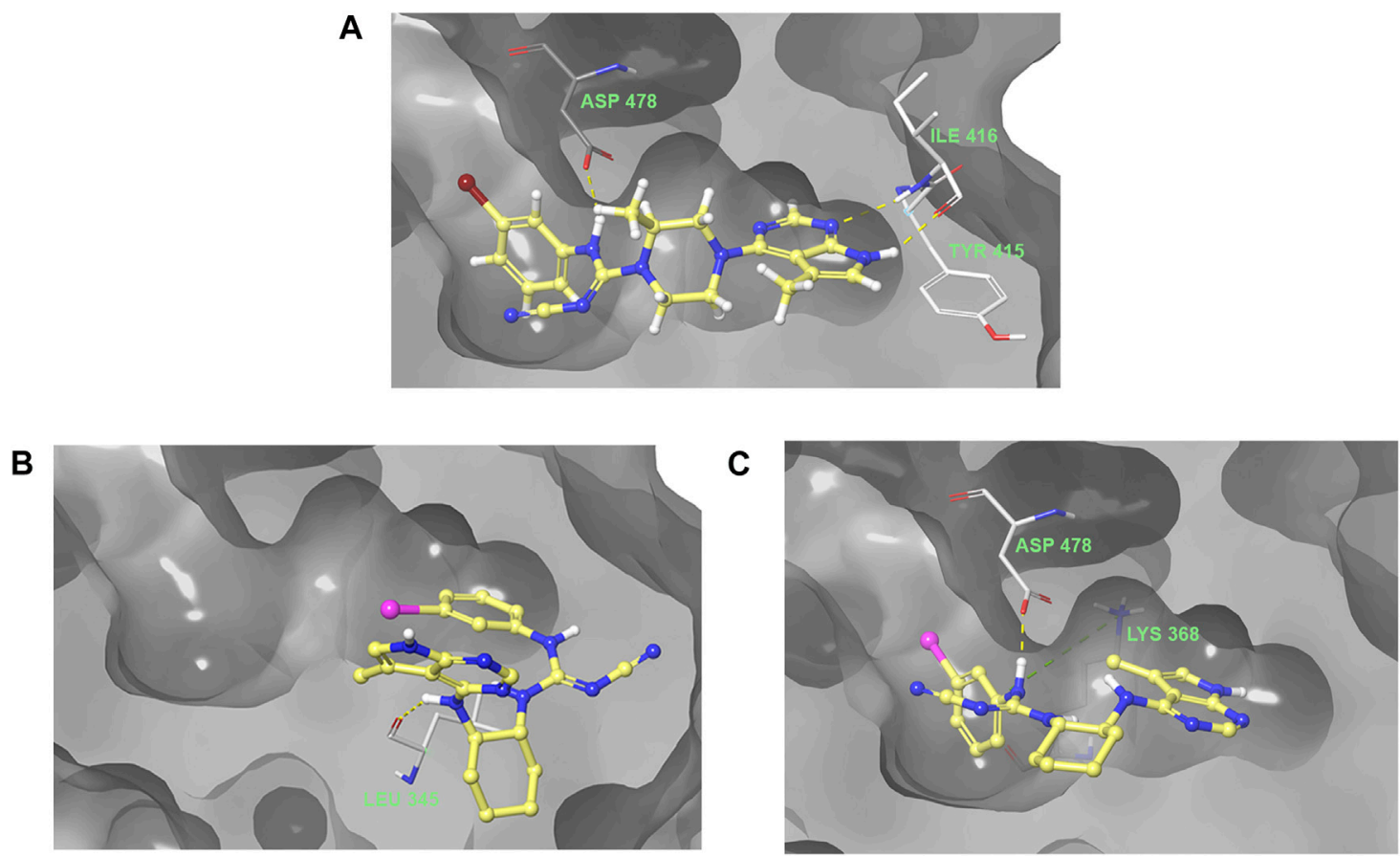

FIGURE 4 | Predicted binding poses of ligand $\mathbf{1}$ (A), 24 (B), and 26 (C) into the ATP-binding pocket of LIMK1.

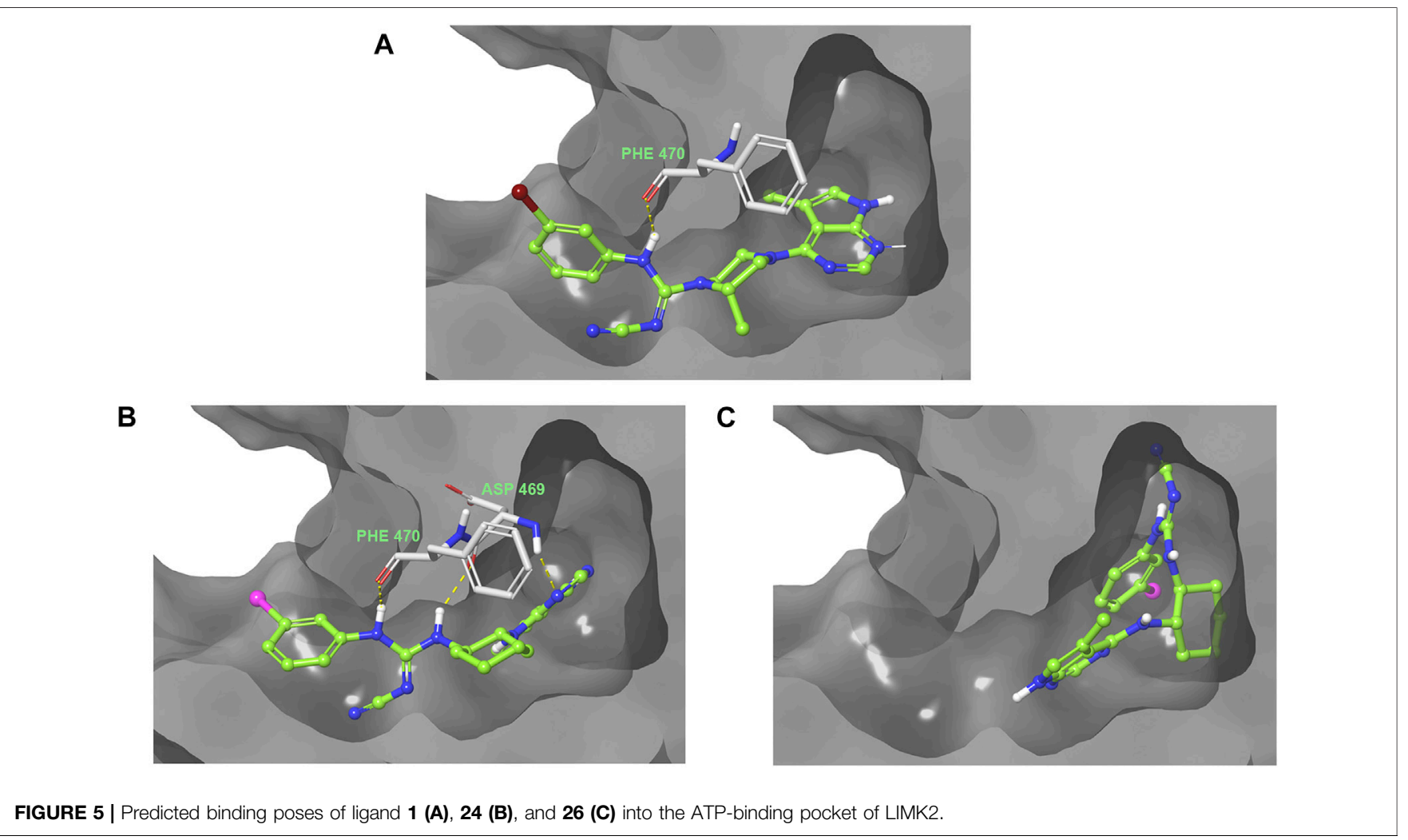


TABLE 1 | Synthesis of initial investigation of linker chain and halide substitutions.<smiles>[X]c1cccc(NC(=NC#N)NC2CCC(Nc3ncnc4[nH]cc(C)c34)C2)c1</smiles>

Compound

(Continued in next column)
TABLE 1 | (Continued) Synthesis of initial investigation of linker chain and halide substitutions.

\begin{tabular}{llcc} 
Compound & $\mathbf{X}=\begin{array}{c}\text { \% LIMK1 inhibition at } \\
\mathbf{0 . 1} \boldsymbol{\mu M}^{\mathbf{2}}\end{array}$ \\
\hline 19
\end{tabular}

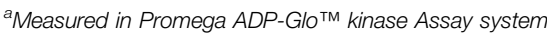

${ }^{b}$ No inhibition at $0.1 \mathrm{uM}$.

Our in-house measurement of LIMK1 inhibition resulted in $>90 \%$ inhibition at $0.1 \mu \mathrm{M}$ for all the 1,2-diaminocyclohexyl analogues (23-26) (Table 2). Similar results were also achieved with the lead compound (1) and its iodide analogue (22). Given this high potency toward LIMK1, we next investigated the selectivity profile of these compounds. LIMK1 and LIMK2 exhibit the same domain architecture and have overlapping substrate specificities. While targeting LIMK1 has been used in vivo in cancer (Zhang et al., 2021) and AD mouse models (Henderson et al., 2019), LIMK2 functionality is essential for proper functionality of the eye (Rice et al., 2012) and in spermatogenesis (Takahashi et al., 2002). Thus, a specific LIMK1 isoform inhibition is desirable.

To measure the selectivity against LIMK isoforms, the radiotracer assay measuring the transfer of ${ }^{33} \mathrm{P}$ from ATP to the substrate was used since there was no ADP-Glo ${ }^{\mathrm{TM}}$ kinase assay system available for LIMK2 (Table 2). Substitution of bromide in compound $\mathbf{1}$ to iodide in compound $\mathbf{2 2}$ resulted in a twofold potency increase for both LIMK1 and LIMK2. Compounds 23-26 were significantly less potent than compounds $\mathbf{1}$ and 22. Interestingly, however, the stereochemistry of the cyclohexyl linker changed the inhibitory bias toward LIMK1 over LIMK2. Compounds 25 and 26 bearing the $(R, R)-1,2-$ cyclohexyl linker were selective toward LIMK1, with no significant inhibition of LIMK2. For comparison, compounds 23 and $\mathbf{2 4}$ bearing the $(S, S)$-1,2-cyclohexyl linker had a slightly higher potency toward LIMK2 than LIMK1.

\section{Scratch Assay}

Cofilin, the substrate for LIMK1, regulates the actin skeleton and thus regulates cell migration (Bravo-Cordero et al., 2013). To understand the inhibitory effect of compounds 1 and 22-26 in vitro, scratch assays were performed. The artificial wound was created by "scratching" in the middle of the well with confluent C6 cells in culture. Live imaging was captured for $24 \mathrm{~h}$ to measure the distance of cell migration (Figure 3; Supplementary video).

All compounds tested in the scratch assay showed significant reduction in cell migration velocity. Among the cyclohexyl analogues 23-26, there is no significant difference in the cell velocity. The lead compound $\mathbf{1}$ reduced the cell velocity by twofold compared to the untreated cell. Substitution from 
TABLE 2 | Inhibition profile of diaminocyclohexyl linker analogues.<smiles>[X]c1cccc(NC(=NC#N)N2CCN(c3ncnc4[nH]cc(C)c34)C[C@H]2C)c1</smiles>

1,22<smiles>[X]c1cccc(NC(=NC)N[C@@H]2CCCC[C@H]2Nc2ncnc3[nH]cc(C)c23)c1</smiles>

23, 24<smiles>[X]c1cccc(NC(=NC#N)N[C@@H]2CCCC[C@H]2Nc2ncnc3[nH]cc(C)c23)c1</smiles>

25,26

\begin{tabular}{|c|c|c|c|c|}
\hline \multirow[t]{2}{*}{ Compound } & \multirow[t]{2}{*}{$\mathbf{X}=$} & \multirow{2}{*}{$\begin{array}{c}\% \text { LIMK1 inhibition at } \\
0.1 \mu \mathrm{M}^{\mathrm{a}}\end{array}$} & \multicolumn{2}{|c|}{$\mathrm{IC}_{50}(\mathrm{nM})^{\mathrm{b}}$} \\
\hline & & & LIMK1 & LIMK2 \\
\hline 22 & 1 & $95.5 \pm 0.4$ & $0.13 \pm 0.01$ & $0.47 \pm 0.01$ \\
\hline 23 & $\mathrm{Br}$ & $96.7 \pm 0.1$ & $2,830 \pm 37$ & $2,651 \pm 15$ \\
\hline 24 & 1 & $93.2 \pm 1.2$ & $5,083 \pm 14$ & $3,380 \pm 19$ \\
\hline
\end{tabular}

${ }^{\text {a }}$ Measured in Promega ADP-GloTM kinase Assay system.

${ }^{b}$ Measured on the transfer of ${ }^{33} \mathrm{P}$-labelled phosphate from ATP, to the kinase substrate (cofilin) by Reaction Biology Corporation.

cInhibition at $10 \mu \mathrm{M}$.

bromide to iodide in compound 22 lowered the migration even further. Overall, the cell migration velocity reflects the $\mathrm{IC}_{50}$ value measured by the radiotracer assay (Reaction Biology Corporation). Thus, it can be implied that these inhibitors work by hindering the binding of ATP into LIMK.

\section{Docking Study}

Docking studies were performed for piperazine and cyclohexyl analogues to rationalise the selectivity trends against LIMK1 and LIMK2. A published crystal structure of LIMK1 (PDB: 5NXC) (Mathea et al., 2017) and LIMK2 (PDB: 4TPT) (Goodwin et al., 2015) bound with inhibitor formed the basis for our docking study, which we performed using Schrodinger GLIDE. Redocking the ligand from the crystal structure generated a binding pose with $\mathrm{RMSD}<2.0 \AA$, providing confidence that the docking protocol is reliable (Supplementary Figures S1, S2).

The predicted binding pose of $\mathbf{1}$ to LIMK1 is shown in Figure 4. The key interaction of compound $\mathbf{1}$ includes hydrogen bonding of pyrrolopyrimidine moiety to Ile 416 and hydrogen bonding of cyanoguanidine moiety to Asp 478 of LIMK1. Hydrogen bonding with Ile 416 is detrimental for this potency as shown by previous structure-activity studies (Cui et al., 2015; Yin et al., 2015). It is important to note that the hydrophobic interaction around piperazine and aryl moieties also contributes to high potency of compound $\mathbf{1}$.

Incorporation of the 1,2-diamino cyclohexyl motif changed the $3 \mathrm{D}$ structure of the ligand and thus changed the binding pose into the ATP-binding pocket of LIMK1. Docking of ligand $\mathbf{2 4}$ resulted in a binding pose with the iodophenyl moiety facing toward the inside of the binding pocket. Compound 26 maintained the hydrogen bonding of the cyanoguanidine moiety to Asp 478 while losing the hydrogen bonding to Ile 416 due to the rigidity of the cyclohexyl group. The absence of hydrogen bonding into Ile 416 could be the reason for the reduction in potency.

The predicted binding pose toward LIMK2 is shown in Figure 5. Lead compound $\mathbf{1}$ formed a hydrogen bond between the cyanoguanidine moiety with Phe 470 of LIMK2. Although it only formed 1 hydrogen bond, the hydrophobic interaction with the surface residue could be accounted for its high potency. Compound $\mathbf{2 4}$ also formed hydrogen bonding with Phe 470, but the cyclohexyl moiety is directed differently compared to piperazine moiety in compound $\mathbf{1}$. Due to this orientation, the hydrophobic interaction within the middle binding tunnel is different, which accounts for the different potency. Compound 26 bearing the $(R, R)$-cyclohexyl motif resulted in a binding pose with the iodophenyl moiety facing toward the inside of the binding pocket. This could be the reason for the lower inhibitory effect of $\mathbf{2 6}$ toward LIMK2.

Overall, changing the stereochemistry of the cyclohexyl group resulted in the switch of the binding pose. The orientation of the pyrrolopyrimidine moiety was detrimental to selectivity. When the pyrrolopyrimidine was oriented into the interior of one of the LIMK isoforms while facing outside on the other isoform, a binding selectivity was achieved.

\section{CONCLUSION}

A series of new LIMK inhibitors have been synthesised based on lead compound $\mathbf{1}$, in which the central linker portion is designed with a certain degree of flexibility. We identify the 
stereochemistry of 1,2-diaminocyclohexyl moiety as detrimental to LIMK isoform selectivity. The docking study revealed that these subtle stereochemistry differences alter the binding pose which reform the ligand-binding site interaction. We also investigated the effect of halogen substitution. We found that substitution of bromide to iodide in compound $\mathbf{2 2}$ improved the potency of lead compound 1. Taken together, the selectivity achieved in this work will be valuable in aiding the development of more potent yet selective LIMK inhibitors for future studies.

\section{MATERIALS AND METHODS}

\section{Chemistry}

All chemicals were purchased from a commercial source and used without any further purification. All HPLC purifications were performed in Shimadzu LC-20 AD equipped with a fraction collector. ${ }^{1} \mathrm{H}-\mathrm{NMR}$ and ${ }^{13} \mathrm{C}-\mathrm{NMR}$ were recorded on Bruker AVIIIHD 400 and $500 \mathrm{MHz}$. All melting points were measured in Stuart Digital SMP10. Mass spectrometry was measured on Shimadzu LC-MS 8050.

General synthetic procedure A: the mixture of pyrrolopyrimidine ( $1 \mathrm{mmol})$, diamino alkane $(5 \mathrm{mmol})$, and DIPEA $(3 \mathrm{mmol})$ in isopropanol $(10 \mathrm{ml})$ was stirred at reflux overnight. Water was added to the reaction mixture, and the mixture was lyophilised. The crude product was purified with semi-preparative HPLC using the gradient of acetonitrile/water with $0.1 \%$ formic acid.

General synthetic procedure B: the mixture of 3-haloanoline $(1 \mathrm{mmol})$ and diphenyl-N-cyanocarbonimidate $(1 \mathrm{mmol})$ in acetonitrile $(15 \mathrm{ml})$ was heated at $50^{\circ} \mathrm{C}$ overnight. The mixture was then cooled in ice bath, resulting in precipitation of the product. The crystalline solid was collected by filtration. The product was used for the next step without any further purification.

General synthetic procedure C: the amino or piperazine substituted pyrrolopyrimidine $(1 \mathrm{mmol})$, phenyl carbaimidates $(2 \mathrm{mmol})$, and $\mathrm{Et}_{3} \mathrm{~N}(3 \mathrm{mmol})$ in acetonitrile $(7 \mathrm{ml})$ and methanol $(3 \mathrm{ml})$ was stirred at reflux overnight. Water was added to the reaction mixture, and the mixture was lyophilised. The crude product was purified with semi-preparative HPLC using gradient of acetonitrile/water with $0.1 \%$ formic acid.

(S)-Methyl piperazine 20: the mixture of pyrrolopyrimidine 5 (1.2 mmol), (S)-tert-butyl 2-methylpiperazine-1-carboxylate $(3.6 \mathrm{mmol})$, and DIPEA $(3.6 \mathrm{mmol})$ in isopropanol $(10 \mathrm{ml})$ was stirred at reflux overnight. The mixture was concentrated under vacuum. The residue was dissolved in 50\% TFA in dichloromethane $(10 \mathrm{ml})$ and stirred overnight at $\mathrm{rt}$. The reaction was concentrated under vacuum, diluted with dichloromethane, and neutralised with sat. aq. sodium bicarbonate. The layers were separated, and the aqueous layer was back extracted with more dichloromethane. The combined organic layers were dried over $\mathrm{MgSO}_{4}$ and concentrated under vacuum. The crude product was purified with semi-preparative HPLC using the gradient of acetonitrile/water with $0.1 \%$ formic acid.

1-(3-Chlorophenyl)-2-cyano-3-(2-((5-methyl-7H-pyrrolo[2,3d]pyrimidin-4-yl)amino)ethyl)guanidine (8). Total yield: $31 \%$. Purity: >99\%. mp: $87-88^{\circ} \mathrm{C}$. ${ }^{1} \mathrm{H}$ NMR (DMSO-d $\left.6,400 \mathrm{MHz}\right): \delta$ $11.2(\mathrm{~s}, 1 \mathrm{H}), 9.2(\mathrm{~s}, 1 \mathrm{H}), 7.98-7.82(\mathrm{~m}, 2 \mathrm{H}), 7.36-7.23(\mathrm{~m}, 2 \mathrm{H})$,
7.21-7.10 (m, 2H), $6.77(\mathrm{~m}, 1 \mathrm{H}), 6.65(\mathrm{~m}, 1 \mathrm{H}), 3.59(\mathrm{~m}, 2 \mathrm{H}), 3.40$ (m, $2 \mathrm{H}), 2.30(\mathrm{~d}, J=1.1 \mathrm{~Hz}, 3 \mathrm{H}) ;{ }^{13} \mathrm{C}$ NMR $\left(\mathrm{DMSO}-\mathrm{d}_{6}, 100 \mathrm{MHz}\right)$ : $\delta 163.5,158.7,157.1,150.9,139.9,133.4,130.8,124.8,123.6,122.4$, 119.4, 117.6, 109.0, 102.8, 42.6, 12.7; ESI-MS: [M + H] calc. 369.13, found 369.30. HR-MS (ESI+): [M + H] calc. 369.1343, found 369.1335 .

1-(3-Bromophenyl)-2-cyano-3-(2-((5-methyl-7H-pyrrolo [2,3-d]pyrimidin-4-yl)amino)ethyl)guanidine (9). Total yield: $20 \%$. Purity: $>99 \%$. mp: $86-88^{\circ} \mathrm{C} .{ }^{1} \mathrm{H}$ NMR (MeOD, $400 \mathrm{MHz}): \delta 9.36(\mathrm{~s}, 1 \mathrm{H}), 8.08(\mathrm{~s}, 1 \mathrm{H}), 7.39(\mathrm{~m}, 1 \mathrm{H}), 7.31$ $(\mathrm{d}, J=7.8 \mathrm{~Hz}, 1 \mathrm{H}), 7.28(\mathrm{~m}, 1 \mathrm{H}), 7.23-7.19(\mathrm{~m}, 2 \mathrm{H}), 7.15-7.00$ $(\mathrm{m}, 3 \mathrm{H}), 3.69(\mathrm{t}, J=5.1 \mathrm{~Hz}, 2 \mathrm{H}), 3.55(\mathrm{dd}, J=6.1,4.4 \mathrm{~Hz}, 2 \mathrm{H})$, $2.40(\mathrm{~d}, J=1.1 \mathrm{~Hz}, 3 \mathrm{H}) ;{ }^{13} \mathrm{C} \mathrm{NMR}(\mathrm{MeOD}, 125 \mathrm{MHz}): \delta 164.4$, $159.2,131.7,130.6,130.5,130.1,129.8,129.0,127.6,127.5$, $123.3,120.5,114.8,113.5,41.0,41.0,10.7$; ESI-MS: $[\mathrm{M}+\mathrm{H}]$ calc. 413.08 , found 413.30. HR-MS (ESI+): $[\mathrm{M}+\mathrm{H}]$ calc. 413.0838, found 413.0827 .

2-Cyano-1-(3-iodophenyl)-3-(2-((5-methyl-7H-pyrrolo[2,3d]pyrimidin-4-yl)amino)ethyl)guanidine (10). Total yield: $5 \%$. Purity: >99\%. mp: $88-89^{\circ} \mathrm{C}{ }^{1} \mathrm{H}$ NMR (MeOD, $400 \mathrm{MHz}$ ): $\delta 9.35$ $(\mathrm{s}, 1 \mathrm{H}), 8.05(\mathrm{~s}, 1 \mathrm{H}), 7.80(\mathrm{t}, J=1.9 \mathrm{~Hz}, 1 \mathrm{H}), 7.61-7.56(\mathrm{~m}, 2 \mathrm{H})$, 7.48-7.37 (m, 3H), 7.05-6.99 (m, 2H), $3.67(\mathrm{t}, J=6.0 \mathrm{~Hz}, 2 \mathrm{H})$, $3.53(\mathrm{dd}, J=4.1,5.7 \mathrm{~Hz}, 2 \mathrm{H}), 2.39(\mathrm{~d}, J=1.1 \mathrm{~Hz}, 3 \mathrm{H}) ;{ }^{13} \mathrm{C} \mathrm{NMR}$ (MeOD, $125 \mathrm{MHz}): \delta 164.4,162.9,159.2,137.5,136.6,132.5$, $130.6,130.1,129.9,128.1,123.7,118.6,114.3,92.4,46.6,41.1$, 10.7; ESI-MS: [M + H] calc. 461.06, found 461.25. HR-MS (ESI+): $[\mathrm{M}+\mathrm{H}]$ calc. 461.0699, found 461.0689.

1-(3-Chlorophenyl)-2-cyano-3-(3-((5-methyl-7H-pyrrolo [2,3- $d]$ pyrimidin-4-yl)amino)propyl)guanidine (11). Total yield: 7\%. Purity: >99\%. mp: $88-90{ }^{\circ} \mathrm{C} .{ }^{1} \mathrm{H}$ NMR (MeOD, $400 \mathrm{MHz}): \delta 7.68(\mathrm{~s}, 1 \mathrm{H}), 7.32-7.25(\mathrm{~m}, 2 \mathrm{H}), 7.20-7.11(\mathrm{~m}$, $2 \mathrm{H}), 6.70(\mathrm{~d}, J=1.1 \mathrm{~Hz}, 1 \mathrm{H}), 3.53(\mathrm{t}, J=6.2 \mathrm{~Hz}, 2 \mathrm{H}), 3.29(\mathrm{t}$, $J=6.4 \mathrm{~Hz}, 2 \mathrm{H}), 2.35(\mathrm{~d}, J=1.1 \mathrm{~Hz}, 3 \mathrm{H}), 1.80-1.72(\mathrm{~m}, 2 \mathrm{H}) ;{ }^{13} \mathrm{C}$ NMR (MeOD, $100 \mathrm{MHz}): \delta 158.8,150.1,138.4,134.5,130.4$, 129.0, 125.9, 124.7, 122.9, 118.8, 117.5, 114.8, 109.8, 102.5, 38.3, 37.0, 29.5, 10.9; ESI-MS: [M + H] calc. 383.14, found 383.25. HRMS (ESI+): $[\mathrm{M}+\mathrm{H}]$ calc. 383.1499, found 383.1492.

1-(3-Bromophenyl)-2-cyano-3-(3-((5-methyl-7H-pyrrolo [2,3- $d]$ pyrimidin-4-yl)amino)propyl)guanidine 12). Total yield: $30 \%$. Purity: >99\%. mp: $88-89^{\circ} \mathrm{C} .{ }^{1} \mathrm{H}$ NMR (MeOD, $400 \mathrm{MHz}): \delta 7.67(\mathrm{~s}, 1 \mathrm{H}), 7.43(\mathrm{~m}, 1 \mathrm{H}), 7.32(\mathrm{~m}, 1 \mathrm{H})$, 7.26-7.17 (m, 2H), 7.08-7.02 (m, 1H), 6.73-6.63 (m, 2H), 3.53 $(\mathrm{t}, J=6.5 \mathrm{~Hz}, 2 \mathrm{H}), 3.29(\mathrm{t}, J=6.5 \mathrm{~Hz}, 2 \mathrm{H}), 2.35(\mathrm{~d}, J=1.1 \mathrm{~Hz}, 3 \mathrm{H})$, $1.76(\mathrm{~m}, 2 \mathrm{H}) ;{ }^{13} \mathrm{C} \mathrm{NMR}(\mathrm{MeOD}, 100 \mathrm{MHz}): \delta 158.8,157.2,150.0$, $149.1,138.5,130.6,128.9,127.6,123.4,118.9,114.8,109.8,102.5$, 38.3, 36.7, 29.5, 10.8; ESI-MS: [M + H] calc. 427.09, found 427.25. HR-MS (ESI+): [M + H] calc. 427.0994, found 427.0986.

2-Cyano-1-(3-iodophenyl)-3-(3-((5-methyl-7H-pyrrolo[2,3d]pyrimidin-4-yl)amino)propyl)guanidine (13). Total yield: 17\%. Purity: >99\%. mp: $91-93^{\circ} \mathrm{C} .{ }^{1} \mathrm{H}$ NMR (MeOD, $400 \mathrm{MHz}): \delta 7.62(\mathrm{t}, J=1.8 \mathrm{~Hz}, 2 \mathrm{H}), 7.52(\mathrm{~d}, J=7.9 \mathrm{~Hz}, 1 \mathrm{H})$, $7.23(\mathrm{~m}, 1 \mathrm{H}), 7.09-7.02(\mathrm{~m}, 2 \mathrm{H}), 6.71-6.64(\mathrm{~m}, 2 \mathrm{H}), 3.53(\mathrm{t}, J=$ $6.4 \mathrm{~Hz}, 2 \mathrm{H}), 3.28(\mathrm{t}, J=6.4 \mathrm{~Hz}, 2 \mathrm{H}), 2.35(\mathrm{~d}, J=1.1 \mathrm{~Hz}, 3 \mathrm{H}), 1.75$ $(\mathrm{m}, 2 \mathrm{H}) ;{ }^{13} \mathrm{C}$ NMR (MeOD, $\left.100 \mathrm{MHz}\right): \delta$ 158.8, 157.3, 150.1, $149.1,138.3,135.0,130.7,129.0,124.1,118.8,117.5,114.8,109.8$, 102.5, 38.2, 37.0, 29.6, 10.9; ESI-MS: [M + H] calc. 475.07, found 475.30. HR-MS (ESI+): [M + H] calc. 475.0856, found 475.0847 . 


\section{1-(3-Chlorophenyl)-2-cyano-3-(4-((5-methyl-7H-pyrrolo} [2,3-d]pyrimidin-4-yl)amino)butyl)guanidine (14). Total yield: 55\%. Purity: >99\%. mp: $90-91^{\circ} \mathrm{C} .{ }^{1} \mathrm{H}$ NMR (MeOD, $\left.400 \mathrm{MHz}\right): \delta$ $7.94(\mathrm{~s}, 1 \mathrm{H}), 7.21(\mathrm{t}, J=8.1 \mathrm{~Hz}, 1 \mathrm{H}), 7.19(\mathrm{~d}, J=2.1 \mathrm{~Hz}, 1 \mathrm{H}), 7.10$ $(\mathrm{m}, 1 \mathrm{H}), 7.08-7.02(\mathrm{~m}, 2 \mathrm{H}), 6.71(\mathrm{~d}, J=1.1 \mathrm{~Hz}, 1 \mathrm{H}), 6.67(\mathrm{~m}, 1 \mathrm{H})$, $3.48(\mathrm{t}, J=6.4 \mathrm{~Hz}, 2 \mathrm{H}), 3.25(\mathrm{t}, J=6.4 \mathrm{~Hz}, 2 \mathrm{H}), 2.33(\mathrm{~d}, J=1.1 \mathrm{~Hz}$, $3 \mathrm{H}), 1.68-1.54(\mathrm{~m}, 4 \mathrm{H}) ;{ }^{13} \mathrm{C} \mathrm{NMR}(\mathrm{MeOD}, 100 \mathrm{MHz}): \delta 158.6$, $156.9,150.0,138.6,134.3,130.2,128.9,125.4,124.1,122.3,118.9$, 114.8, 109.8, 102.6, 41.3, 40.0, 26.5, 26.3, 10.8; ESI-MS: [M + H] calc. 397.16, found 397.25. HR-MS (ESI+): $[\mathrm{M}+\mathrm{H}]$ calc. 397.1656 , found 397.1650 .

1-(3-Bromophenyl)-2-cyano-3-(4-((5-methyl-7H-pyrrolo [2,3-d]pyrimidin-4-yl)amino)butyl)guanidine (15). Total yield: 47\%. Purity: >99\%. mp: 97-98 ${ }^{\circ} \mathrm{C} .{ }^{1} \mathrm{H}$ NMR (MeOD, $400 \mathrm{MHz}$ ): $\delta$ $7.94(\mathrm{~s}, 1 \mathrm{H}), 7.35(\mathrm{t}, J=1.8 \mathrm{~Hz}, 1 \mathrm{H}), 7.25(\mathrm{~m}, 1 \mathrm{H}), 7.15(\mathrm{t}, J=$ $8.0 \mathrm{~Hz}, 1 \mathrm{H}), 7.10(\mathrm{~m}, 1 \mathrm{H}), 7.05(\mathrm{~m}, 1 \mathrm{H}), 6.72-6.63(\mathrm{~m}, 2 \mathrm{H}), 3.48$ $(\mathrm{t}, J=6.9 \mathrm{~Hz}, 2 \mathrm{H}), 3.25(\mathrm{t}, J=6.9 \mathrm{~Hz}, 2 \mathrm{H}), 2.33(\mathrm{~d}, J=1.1 \mathrm{~Hz}, 3 \mathrm{H})$, $1.67-1.55(\mathrm{~m}, 4 \mathrm{H}) ;{ }^{13} \mathrm{C}$ NMR (MeOD, $\left.100 \mathrm{MHz}\right): \delta 158.6,156.9$, $149.9,149.1,138.7,130.4,129.0,128.4,127.0,122.8,118.9,114.8$, 109.8, 102.6, 41.3, 40.0, 26.5, 26.3, 10.8; ESI-MS: $[\mathrm{M}+\mathrm{H}]$ calc. 441.11, found 441.30. HR-MS (ESI+): [M + H] calc. 441.1151, found 441.1141.

2-Cyano-1-(3-iodophenyl)-3-(4-((5-methyl-7H-pyrrolo[2,3d]pyrimidin-4-yl)amino)butyl)guanidine (16). Total yield: 53\%. Purity: >99\%. mp: $90-911^{\circ} \mathrm{C} .{ }^{1} \mathrm{H}$ NMR (MeOD, $400 \mathrm{MHz}): \delta 7.94(\mathrm{~s}, 1 \mathrm{H}), 7.53(\mathrm{t}, J=1.7 \mathrm{~Hz}, 1 \mathrm{H}), 7.45(\mathrm{~m}$, $1 \mathrm{H}), 7.13(\mathrm{~m}, 1 \mathrm{H}), 7.08-6.97(\mathrm{~m}, 2 \mathrm{H}), 6.72-6.64(\mathrm{~m}, 2 \mathrm{H}), 3.48(\mathrm{t}$, $J=6.7 \mathrm{~Hz}, 2 \mathrm{H}), 3.24(\mathrm{t}, J=6.9 \mathrm{~Hz}, 2 \mathrm{H}), 2.33(\mathrm{~d}, J=1.2 \mathrm{~Hz}, 3 \mathrm{H})$, 1.67-1.54 (m, 4H); ${ }^{13} \mathrm{C}$ NMR (MeOD, $\left.125 \mathrm{MHz}\right): \delta 158.6,156.9$, $149.9,138.4,134.6,133.0,130.5,129.0,123.5,118.9,117.5,114.8$, 109.9, 102.6, 41.3, 40.0, 26.5, 26.3, 10.8; ESI-MS: $[\mathrm{M}+\mathrm{H}]$ calc. 489.09, found 489.30. HR-MS (ESI+): [M + H] calc. 489.1012, found 489.1002 .

1-(3-Chlorophenyl)-2-cyano-3-((1r,4r)-4-((5-methyl7H-pyrrolo[2,3-d]pyrimidin-4-yl)amino)cyclohexyl)guanidine (17). Total yield: $3 \%$. Purity: $>99 \%$. mp: $120-122{ }^{\circ} \mathrm{C} .{ }^{1} \mathrm{H}$ NMR (MeOD, $400 \mathrm{MHz}$ ): $\delta 7.94$ (s, 1H), 7.29-7.19 (m, 2H), 7.14-7.06 $(\mathrm{m}, 2 \mathrm{H}), 6.71(\mathrm{~d}, J=1.2 \mathrm{~Hz}, 1 \mathrm{H}), 3.95(\mathrm{~m}, 1 \mathrm{H}), 3.74(\mathrm{~m}, 1 \mathrm{H}), 2.33$ (d, $J=1.1 \mathrm{~Hz}, 3 \mathrm{H}), 2.09-1.93(\mathrm{~m}, 4 \mathrm{H}), 1.50-1.37(\mathrm{~m}, 4 \mathrm{H}) ;{ }^{13} \mathrm{C}$ NMR (MeOD, $125 \mathrm{MHz}$ ): $\delta$ 157.7, 156.6, 150.4, 149.5, 138.9, $134.4,130.2,125.1,123.4,121.7,118.9,117.3,109.5,102.7,50.7$, 48.6, 31.0, 30.8, 10.7; ESI-MS: [M + H] calc. 423.17, found 423.35. HR-MS (ESI+): [M + H] calc. 423.1812, found 423.1805.

1-(3-Bromophenyl)-2-cyano-3-((1r,4r)-4-((5-methyl7H-pyrrolo[2,3-d]pyrimidin-4-yl)amino)cyclohexyl)guanidine (18). Total yield: $16 \%$. Purity: $>99 \%$. mp: $127-128^{\circ} \mathrm{C} .{ }^{1} \mathrm{H}$ NMR $(\mathrm{MeOD}, 400 \mathrm{MHz}): \delta 7.94(\mathrm{~s}, 1 \mathrm{H}), 7.36(\mathrm{t}, J=1.9 \mathrm{~Hz}, 1 \mathrm{H}), 7.26$ $(\mathrm{m}, 1 \mathrm{H}), 7.19(\mathrm{t}, J=8.0 \mathrm{~Hz}, 1 \mathrm{H}), 7.13(\mathrm{~m}, 1 \mathrm{H}), 6.72(\mathrm{~d}, J=1.2 \mathrm{~Hz}$, $1 \mathrm{H}), 3.94(\mathrm{~m}, 1 \mathrm{H}), 3.73(\mathrm{~m}, 1 \mathrm{H}), 2.33(\mathrm{~d}, J=1.1 \mathrm{~Hz}, 3 \mathrm{H})$, 2.09-1.92 (m, 4H), 1.51-1.37 (m, 4H); ${ }^{13} \mathrm{C}$ NMR (MeOD, $100 \mathrm{MHz}): \delta 157.7,156.5,150.2,149.4,139.0,130.4,128.0$, $126.3,122.1,122.1,119.0,117.3,109.6,102.6,50.7,48.7,31.0$, 30.8, 10.7; ESI-MS: [M + H] calc. 467.12, found 467.30. HR-MS (ESI+): $[\mathrm{M}+\mathrm{H}]$ calc. 467.1307 , found 467.1297 .

2-Cyano-1-(3-iodophenyl)-3-((1r,4r)-4-((5-methyl-

7H-pyrrolo[2,3-d]pyrimidin-4-yl)amino)cyclohexyl)guanidine (19). Total yield: $11 \%$. Purity: $>99 \%$. mp: $129-130^{\circ}$ C. ${ }^{1} \mathrm{H}$ NMR
(MeOD, $400 \mathrm{MHz}): \delta 9.36(\mathrm{~s}, 1 \mathrm{H}), 8.02(\mathrm{~s}, 1 \mathrm{H}), 7.59$ (dt, $J=7.5$, $1.5 \mathrm{~Hz}, 1 \mathrm{H}), 7.54(\mathrm{t}, J=1.8 \mathrm{~Hz}, 1 \mathrm{H}), 7.46(\mathrm{~m}, 1 \mathrm{H}), 7.38(\mathrm{t}, J=$ $2.0 \mathrm{~Hz}, 1 \mathrm{H}), 7.16(\mathrm{~m}, 1 \mathrm{H}), 7.07-7.01(\mathrm{~m}, 2 \mathrm{H}), 2.37(\mathrm{~d}, J=1.1 \mathrm{~Hz}$, $3 \mathrm{H}), 2.02(\mathrm{~m}, 4 \mathrm{H}), 1.64-1.36(\mathrm{~m}, 4 \mathrm{H}) ;{ }^{13} \mathrm{C} \mathrm{NMR}(\mathrm{MeOD}$, $125 \mathrm{MHz}): \delta 164.4,157.7,137.5,136.5,134.3,132.4,130.5$, $129.9,128.1,122.8,120.0,117.3,114.0,93.4,50.5,49.4,30.7$, 30.7, 10.6; ESI-MS: $[\mathrm{M}+\mathrm{H}]$ calc. 515.11, found 515.30. HR-MS (ESI+): $[\mathrm{M}+\mathrm{H}]$ calc. 515.1169, found 515.1159.

(S)- $N^{\prime}$-Cyano- $N$-(3-iodophenyl)-2-methyl-4-(5-methyl7H-pyrrolo[2,3-d]pyrimidin-4-yl)piperazine-1-

carboximidamide (22). Total yield: 7\%. Purity: >99\%. mp: $130-131^{\circ} \mathrm{C} .{ }^{1} \mathrm{H}$ NMR (MeOD, $\left.400 \mathrm{MHz}\right): \delta 8.13(\mathrm{~s}, 1 \mathrm{H})$, 7.43-7.36 (m, 2H), 7.07-6.92 (m, 3H), $4.52(\mathrm{~m}, 1 \mathrm{H}), 4.06$ (m, 1H), $3.90(\mathrm{~m}, 1 \mathrm{H}), 3.83(\mathrm{~m}, 1 \mathrm{H}), 3.59(\mathrm{~m}, 1 \mathrm{H}), 3.39(\mathrm{dd}, J=$ 13.1, 3.9 Hz, 1H), $3.09(\mathrm{~m}, 1 \mathrm{H}), 2.36(\mathrm{~d}, J=1.1 \mathrm{~Hz}, 3 \mathrm{H}), 1.24(\mathrm{~d}, J=$ $6.8 \mathrm{~Hz}, 3 \mathrm{H}) ;{ }^{13} \mathrm{C}$ NMR (MeOD, $\left.125 \mathrm{MHz}\right): \delta 161.2,158.4,152.1$, $149.4,140.0,133.1,130.5,130.1,121.6,120.5,116.1,109.1,106.6$, 93.4, 52.1, 50.8, 49.6, 41.4, 15.0, 12.5; ESI-MS: [M + H] calc. 501.09, found 501.20. HR-MS (ESI+): $[\mathrm{M}+\mathrm{H}]$ calc. 501.1012, found 501.1003 .

1-(3-Bromophenyl)-2-cyano-3-((1R,2R)-2-((5-methyl7H-pyrrolo[2,3-d]pyrimidin-4-yl)amino)cyclohexyl)guanidine (23). Total yield: $8 \%$. Purity: $>99 \%$. mp: $127-128^{\circ} \mathrm{C} .{ }^{1} \mathrm{H}$ NMR (MeOD, $400 \mathrm{MHz}): \delta 7.73(\mathrm{~s}, 1 \mathrm{H}), 7.21(\mathrm{~m}, 1 \mathrm{H}), 7.05(\mathrm{t}, J=$ $1.9 \mathrm{~Hz}, 1 \mathrm{H}), 7.00(\mathrm{t}, J=8.0 \mathrm{~Hz}, 1 \mathrm{H}), 6.79(\mathrm{~m}, 1 \mathrm{H}), 6.73(\mathrm{~d}, J=$ $1.2 \mathrm{~Hz}, 1 \mathrm{H}), 4.05(\mathrm{~m}, 1 \mathrm{H}), 3.84(\mathrm{~m}, 1 \mathrm{H}), 2.37(\mathrm{~d}, J=1.2 \mathrm{~Hz}, 3 \mathrm{H})$, $2.03(\mathrm{~m}, 2 \mathrm{H}), 1.72(\mathrm{~m}, 2 \mathrm{H}), 1.49-1.28(\mathrm{~m}, 4 \mathrm{H}) ;{ }^{13} \mathrm{C}$ NMR (MeOD, $100 \mathrm{MHz}): \delta 158.5,157.2,150.4,138.4,136.2,130.4,128.6,126.9$, 122.6, 122.2, 119.1, 117.2, 109.6, 102.6, 56.3, 53.7, 32.1, 31.6, 24.5, 24.4, 10.9; ESI-MS: [M + H] calc. 467.12, found 467.30. HR-MS (ESI+): $[\mathrm{M}+\mathrm{H}]$ calc. 467.1307 , found 467.1297.

2-Cyano-1-(3-iodophenyl)-3-((1R,2R)-2-((5-methyl7H-pyrrolo[2,3- $d]$ pyrimidin-4-yl)amino)cyclohexyl)guanidine (24). Total yield: $9 \%$. Purity: $>99 \%$. mp: $128-129^{\circ} \mathrm{C} .{ }^{1} \mathrm{H}$ NMR (MeOD, $400 \mathrm{MHz}): \delta 7.85(\mathrm{~s}, 1 \mathrm{H}), 7.42(\mathrm{td}, J=7.0,1.8 \mathrm{~Hz}, 1 \mathrm{H})$, $7.26(\mathrm{~m}, 1 \mathrm{H}), 6.90-6.81(\mathrm{~m}, 3 \mathrm{H}), 3.99(\mathrm{~m}, 1 \mathrm{H}), 3.89(\mathrm{~m}, 1 \mathrm{H}), 2.39$ $(\mathrm{d}, J=1.2 \mathrm{~Hz}, 2 \mathrm{H}), 2.03(\mathrm{~m}, 2 \mathrm{H}), 1.72(\mathrm{~m}, 2 \mathrm{H}), 1.52-1.28(\mathrm{~m}, 4 \mathrm{H})$; ${ }^{13} \mathrm{C}$ NMR (MeOD, $\left.125 \mathrm{MHz}\right): \delta$ 158.5, 147.9, 138.1, 134.8, 132.9, $130.5,132.3,120.0,117.0,110.5,102.4,93.5,55.7,54.6,31.8,31.5$, 24.4, 24.3, 10.8; ESI-MS: [M + H] calc. 515.11, found 515.20. HRMS (ESI+): $[\mathrm{M}+\mathrm{H}]$ calc. 515.1169 , found 515.1157 .

1-(3-Bromophenyl)-2-cyano-3-((1S,2S)-2-((5-methyl-

7H-pyrrolo[2,3-d]pyrimidin-4-yl)amino)cyclohexyl)

guanidine (25). Total yield: $7 \%$. Purity: $>99 \%$. mp: $127-128^{\circ} \mathrm{C}$. ${ }^{1} \mathrm{H}$ NMR (MeOD, $\left.400 \mathrm{MHz}\right): \delta 7.72(\mathrm{~s}, 1 \mathrm{H}), 7.21(\mathrm{~m}, 1 \mathrm{H}), 7.05$ $(\mathrm{t}, J=1.9 \mathrm{~Hz}, 1 \mathrm{H}), 7.00(\mathrm{t}, J=8.0 \mathrm{~Hz}, 1 \mathrm{H}), 6.79(\mathrm{~m}, 1 \mathrm{H}), 6.73(\mathrm{~d}$, $J=1.2 \mathrm{~Hz}, 1 \mathrm{H}), 4.04(\mathrm{~m}, 1 \mathrm{H}), 3.85(\mathrm{~m}, 1 \mathrm{H}), 2.37(\mathrm{~d}, J=1.2 \mathrm{~Hz}$, $3 \mathrm{H}), 2.03(\mathrm{~m}, 2 \mathrm{H}), 1.71(\mathrm{~m}, 2 \mathrm{H}), 1.48-1.27(\mathrm{~m}, 4 \mathrm{H}) ;{ }^{13} \mathrm{C} \mathrm{NMR}$ (MeOD, $100 \mathrm{MHz}): \delta 158.4,157.1,150.5,149.6,138.4,130.5$, $128.6,126.9,122.6,122.2,119.1,117.2,109.6,102.6,56.3,53.7$, 32.1, 31.6, 24.5, 24.4, 10.9; ESI-MS: [M+ H] calc. 467.12, found 467.30. HR-MS (ESI+): $[\mathrm{M}+\mathrm{H}]$ calc. 467.1307, found 467.1297.

2-Cyano-1-(3-iodophenyl)-3-((1S,2S)-2-((5-methyl-

7H-pyrrolo[2,3-d]pyrimidin-4-yl)amino)cyclohexyl)guanidine (26). Total yield: $11 \%$. Purity: $>99 \%$. mp: $128-129^{\circ} \mathrm{C} .{ }^{1} \mathrm{H}$ NMR $(\mathrm{MeOD}, 400 \mathrm{MHz}): \delta 7.74(\mathrm{~s}, 1 \mathrm{H}), 7.42(\mathrm{td}, J=7.3,1.6 \mathrm{~Hz}, 1 \mathrm{H})$, 
$7.26(\mathrm{t}, J=2.0 \mathrm{~Hz}, 1 \mathrm{H}), 6.88-6.79(\mathrm{~m}, 2 \mathrm{H}), 6.74(\mathrm{~d}, J=1.1 \mathrm{~Hz}$, $1 \mathrm{H}), 4.03(\mathrm{~m}, 1 \mathrm{H}), 3.85(\mathrm{~m}, 1 \mathrm{H}), 2.37(\mathrm{~d}, J=1.2 \mathrm{~Hz}, 2 \mathrm{H}), 2.03(\mathrm{~m}$, $2 \mathrm{H}), 1.71(\mathrm{~m}, 2 \mathrm{H}), 1.49-1.27(\mathrm{~m}, 4 \mathrm{H}) ;{ }^{13} \mathrm{C}$ NMR (MeOD, $100 \mathrm{MHz}): \delta 158.5,157.1,150.4,149.7,138.2,134.7,132.9$, $130.5,123.3,119.1,117.2,109.6,102.6,93.5,56.2,53.8,32.1$, 31.6, 24.5, 24.4, 10.9; ESI-MS: [M + H] calc. 515.11, found 515.25. HR-MS (ESI+): [M + H] calc. 515.1169, found 515.1157.

\section{In Silico Docking Study}

The molecular docking study of all compounds was carried out in Schrodinger Glide Software package. The 2D structures of the newly synthetic compounds were accurately drawn using ChemDraw 19.0 software and then exported to Schrodinger Maestro. Crystal structures were prepared by downloading the pdf file from the Protein Data Bank (LIMK1: 5NXC; LIMK2: 4TPT). Protein was prepared using protein preparation wizard within the Schrodinger package using default settings. Receptor grids are set up as $10 \AA$ radius around the ATP binding pocket of LIMK. Inhibitors were docked into the receptor using the Glide SP method, and the pose with the lowest GLIDE binding score was selected for study. Schrodinger Maestro 12.7 was then used to visualise the interactions between the ligand molecules and LIMK.

\section{Biological Study LIMK1 ADP-Glo ${ }^{\text {TM }}$ Kinase Assay System}

ADP-Glo kinase assay was performed in 96-well plate format using the Promega kinase assay system. LIMK1 $(0.1 \mu \mathrm{g})$ and compounds $(0.1-100 \mu \mathrm{M})$ were dissolved in kinase reaction buffer and incubated for $30 \mathrm{~min}$ at $\mathrm{rt}$. The reaction was then initiated by the addition of ATP $(10 \mu \mathrm{M}, 5 \mu \mathrm{l})$ and incubation for $30 \mathrm{~min}$ at $30^{\circ} \mathrm{C}$. The reaction was then quenched with addition of $25 \mu \mathrm{l}$ of ADP-Glo reagent. Kinase detection reagent $(50 \mu \mathrm{l})$ was added and incubated for $30 \mathrm{~min}$ prior to luminescence reading on the BMG Labtech PHERAstar FS plate reader. Kinase assay is performed as duplicate.

\section{${ }^{33}$ P-ATP Radiotracer Assay}

The radiotracer assay of LIMK1 and LIMK2 was performed by Reaction Biology Corporation. Compounds were tested in 10dose $\mathrm{IC}_{50}$ mode with fivefold series dilution starting at $10 \mu \mathrm{M}$. Reactions were carried out at $10 \mu \mathrm{M}{ }^{33} \mathrm{P}$-ATP, $1 \mu \mathrm{M}$ cofilin substrate, and $50 \mathrm{nM}$ LIMK1 (final concentration). Kinase activity is determined by the transfer or radioactive ${ }^{33} \mathrm{P}$ from ATP to cofilin substrate. Radiotracer assay is performed as triplicate.

\section{REFERENCES}

Ben Zablah, Y., Merovitch, N., Jia, Z., and Jia, Zhengping. (2020). The Role of ADF/ Cofilin in Synaptic Physiology and Alzheimer's Disease. Front. Cel Dev. Biol. 8 (November), 1-20. doi:10.3389/fcell.2020.594998

Bernard, O. (2007). Lim Kinases, Regulators of Actin Dynamics. Int. J. Biochem. Cel Biol. 39 (6), 1071-1076. doi:10.1016/j.biocel.2006.11.011

\section{Scratch Assay}

The velocity of cell migration is measured using the C6 cell line in the 24 -well plate. Cells were seeded at 100,000 cells/well. After 24 h, cells were washed with warm PBS and treated with the inhibitors. Directly following the treatment, cells were moved into a preheated stage-top incubator maintained at $37^{\circ} \mathrm{C} / 5 \% \mathrm{CO}_{2}$, using the ZEISS Axio Observer live cell microscope, fitted with an Axiocam 702 mono camera. Cells were imaged once every 10 min using a $\times 10$ objective with phase contrast for a 24 -h period. Cell migration was analysed using Fiji ImageJ (NIH) and Chemotaxis Migration Tool (ibidi).

\section{DATA AVAILABILITY STATEMENT}

The original contributions presented in the study are included in the article/Supplementary Material, further inquiries can be directed to the corresponding author.

\section{AUTHOR CONTRIBUTIONS}

DA, LI, and MK designed the study. DA synthesised the compounds and performed the $\mathrm{IC}_{50}$ testing. $\mathrm{CA}$ and $\mathrm{EP}$ performed the scratch assay. TF and $\mathrm{YK}$ supervised the experiments. YK, MK, and LI obtained the funding. DA, LI, and $\mathrm{MK}$ wrote the first draft of the manuscript. All authors reviewed and approved the manuscript.

\section{FUNDING}

This study was supported by the National Health and Medical Research Council $(1123564,1136241,1132524,1143848)$ and Macquarie University.

\section{ACKNOWLEDGMENTS}

The authors acknowledge the Department of Molecular Sciences for access to NMR and melting point instrument.

\section{SUPPLEMENTARY MATERIAL}

The Supplementary Material for this article can be found online at: https://www.frontiersin.org/articles/10.3389/fchem.2021.781213/ full\#supplementary-material

Boland, S., Bourin, A., Alen, J., Geraets, J., Schroeders, P., Castermans, K., et al. (2015). Design, Synthesis and Biological Characterization of Selective LIMK Inhibitors. Bioorg. Med. Chem. Lett. 25 (18), 4005-4010. doi:10.1016/ j.bmcl.2015.07.009

Bravo-Cordero, J. J., Magalhaes, M. A. O., Eddy, R. J., Hodgson, L., Condeelis, J., Hodgson, Louis., et al. (2013). Functions of Cofilin in Cell Locomotion and Invasion. Nat. Rev. Mol. Cel Biol. 14 (7), 405-415. doi:10.1038/ nrm3609 
Cui, J., Ding, M., Deng, W., Yin, Y., Wang, Z., Zhou, H., et al. (2015). Discovery of Bis-Aryl Urea Derivatives as Potent and Selective Limk Inhibitors: Exploring Limk1 Activity and Limk1/ROCK2 Selectivity through a Combined Computational Study. Bioorg. Med. Chem. 23 (23), 7464-7477. doi:10.1016/ j.bmc.2015.10.041

Davila, M., Jhala, D., Ghosh, D., Grizzle, W. E., and Chakrabarti, R. (2007). Expression of LIM Kinase 1 Is Associated with Reversible G1/S Phase Arrest, Chromosomal Instability and Prostate Cancer. Mol. Cancer 6, 1-12. doi:10.1186/1476-4598-6-40

Goodwin, Nicole. C., Cianchetta, Giovanni., Burgoon, Hugh. A., Healy, Jason., Ross, Mabon., Strobel, Eric. D., et al. (2015). Discovery of a Type III Inhibitor of LIM Kinase 2 that Binds in a DFG- Out Conformation. ACS Med. Chem. Lett. 6 (1), 53-57. doi:10.1021/ml500242y

Harrison, B. A., Whitlock, N. A., Voronkov, M. V., Almstead, Z. Y., Gu, K.-j., Mabon, R., et al. (2009). Novel Class of LIM-Kinase 2 Inhibitors for the Treatment of Ocular Hypertension and Associated Glaucoma. J. Med. Chem. 52 (21), 6515-6518. doi:10.1021/jm901226j

Henderson, B. W., Greathouse, K. M., Ramdas, R., Walker, C. K., Rao, Tejeshwar. C., Bach, Svitlana. V., et al. (2019). Pharmacologic Inhibition of LIMK1 Provides Dendritic Spine Resilience against $\beta$-amyloid. Sci. Signal. 12 (587), eaaw9318. doi:10.1126/scisignal.aaw9318

Heredia, L., Helguera, P., De Olmos, S., Kedikian, G., Sola Vigo, F., LaFerla, F., et al. (2006). Phosphorylation of Actin-Depolymerizing Factor/Cofilin by LIMKinase Mediates Amyloid -Induced Degeneration: A Potential Mechanism of Neuronal Dystrophy in Alzheimer's Disease. J. Neurosci. 26 (24), 6533-6542. doi:10.1523/JNEUROSCI.5567-05.2006

Kang, X., Li, W., Liu, W., Liang, H., Deng, J., Wong, C. C., et al. (2021). LIMK1 Promotes Peritoneal Metastasis of Gastric Cancer and Is a Therapeutic Target. Oncogene 40 (19), 3422-3433. doi:10.1038/s41388-021-01656-1

Mathea, S., Salah, E., Pike, A. C. W., Bushell, S., Carpenter, E. P., von Delft, F., et al. (2017). LIM Domain Kinase 1 (LIMK1) in Complex with PF-00477736LIM Domain Kinase (LIMK1) in Complex with PF-00477736. doi:10.2210/ pdb5NXC/pdb

Murphy, M. P., and Levine, H. (2010). 19, 311-323. doi:10.3233/jad-20101221Alzheimer's Disease and the Amyloid- $\beta$ PeptideJ. Alzheimers Dis.

Piccioli, Z. D., and Littleton, J. T. (2014). Retrograde BMP Signaling Modulates Rapid Activity-dependent Synaptic Growth via Presynaptic Lim Kinase Regulation of Cofilin. J. Neurosci. 34 (12), 4371-4381. doi:10.1523/ JNEUROSCI.4943-13.2014

Prunier, C., Prudent, R., Kapur, R., Sadoul, K., and Lafanechère, L. (2017). LIM Kinases: Cofilin and beyond. Oncotarget 8 (25), 41749-41763. doi:10.18632/ oncotarget.16978

Rice, D. S., Hansen, G. M., Liu, F., Crist, M. J., Newhouse, M. M., Potter, D., et al. (2012). Keratinocyte Migration in the Developing Eyelid Requires LIMK2. PLoS ONE 7 (10), e47168-24. doi:10.1371/journal.pone.0047168

Rush, T., Martinez-hernandez, J., Dollmeyer, M., Frandemiche, M. L., Borel, E., Boisseau, S., et al. (2018). Synaptotoxicity in Alzheimer's Disease Involved a Dysregulation of Actin Cytoskeleton Dynamics through Cofilin 1 Phosphorylation. J. Neurosci. 38 (48), 10349-10361. doi:10.1523/ jneurosci.1409-18.2018
Scott, R. W., and Olson, M. F. (2007). LIM Kinases: Function, Regulation and Association with Human Disease. J. Mol. Med. 85 (6), 555-568. doi:10.1007/ s00109-007-0165-6

Shi, W., Ma, D., Cao, Y., Hu, L., Liu, S., Yan, D., et al. (2021). SphK2/S1P Promotes Metastasis of Triple-Negative Breast Cancer through the PAK1/LIMK1/ Cofilin1 Signaling Pathway. Front. Mol. Biosci. 8 (April), 1-13. doi:10.3389/ fmolb.2021.598218

Takahashi, H., Koshimizu, U., Miyazaki, J.-I., and Nakamura, T. (2002). Impaired Spermatogenic Ability of Testicular Germ Cells in Mice Deficient in the LIMKinase 2 Gene. Dev. Biol. 241 (2), 259-272. doi:10.1006/dbio.2001.0512

Tanaka, K., Takeda, S., Mitsuoka, K., Oda, T., Kimura-Sakiyama, C., Maéda, Y., et al. (2018). Structural Basis for Cofilin Binding and Actin Filament Disassembly. Nat. Commun. 9 (1), 1-3. doi:10.1038/s41467-018-04290-w

Vorster, P. J., Guo, J., Yoder, A., Wang, W., Zheng, Y., Xu, X., et al. (2011). LIM Kinase 1 Modulates Cortical Actin and CXCR4 Cycling and Is Activated by HIV-1 to Initiate Viral Infection. J. Biol. Chem. 286 (14), 12554-12564. doi:10.1074/jbc.M110.182238

Wen, X., Ding, L., Wang, J.-J., Qi, M., Hammonds, J., Chu, H., et al. (2014). ROCK1 and LIM Kinase Modulate Retrovirus Particle Release and Cell-Cell Transmission Events. J. Virol. 88 (12), 6906-6921. doi:10.1128/jvi.00023-14

Yi, F., Guo, J., Dabbagh, D., Spear, M., He, S., Kehn-Hall, K., et al. (2017). Discovery of Novel Small-Molecule Inhibitors of LIM Domain Kinase for Inhibiting HIV1. J. Virol. 91 (13), e02418-16. doi:10.1128/JVI.02418-16

Yin, Y., Zheng, K., Eid, N., Howard, S., Jeong, J.-H., Yi, F., et al. (2015). Bis-Aryl Urea Derivatives as Potent and Selective LIM Kinase (Limk) Inhibitors. J. Med. Chem. 58 (4), 1846-1861. doi:10.1021/jm501680m

Yoshioka, K., Foletta, V., Bernard, O., and Itoh, K. (2003). A Role for LIM Kinase in Cancer Invasion. Proc. Natl. Acad. Sci. 100 (12), 7247-7252. doi:10.1073/ pnas. 1232344100

Zhang, M., Wang, R., Tian, J., Song, M., Zhao, R., Liu, K., et al. (2021). Targeting LIMK1 with Luteolin Inhibits the Growth of Lung Cancer In Vitro and In Vivo. J. Cel Mol Med 25 (12), 5560-5571. doi:10.1111/jcmm.16568

Conflict of Interest: The authors declare that the research was conducted in the absence of any commercial or financial relationships that could be construed as a potential conflict of interest.

Publisher's Note: All claims expressed in this article are solely those of the authors and do not necessarily represent those of their affiliated organizations, or those of the publisher, the editors, and the reviewers. Any product that may be evaluated in this article, or claim that may be made by its manufacturer, is not guaranteed or endorsed by the publisher.

Copyright (c) 2021 Ariawan, Au, Paric, Fath, Ke, Kassiou, van Eersel and Ittner. This is an open-access article distributed under the terms of the Creative Commons Attribution License (CC BY). The use, distribution or reproduction in other forums is permitted, provided the original author(s) and the copyright owner(s) are credited and that the original publication in this journal is cited, in accordance with accepted academic practice. No use, distribution or reproduction is permitted which does not comply with these terms. 